\title{
Analysis of Bushfires Spatial and Temporal Variability in Guinea
}

\author{
Tamba Nicolas Millimono1,2, Saïdou Moustapha Sall2, Daouda Badiane², Alassane Bah', \\ Moussa Diakhate², Ibra Toure3, Mamadou Baïlo Barry,2, Diakaria Diallo",2, Idrissa Diaby ${ }^{4}$ \\ ${ }^{1}$ Institut Supérieur des Sciences de l'Education de Guinée (ISSEG), Conakry, Guinea \\ ${ }^{2}$ Laboratoire de Physique de l'Atmosphère et de l'Ocean-Siméon Fongang-UCAD/ESP/LAPOSF, Dakar, Senegal \\ ${ }^{3}$ Centre de Coopération Internationale en Recherche Agronomique pour le Développement (CIRAD), Ouagadougou, Burkina Faso \\ ${ }^{4}$ Laboratoire d'Enseignement et de Recherche en Energétique Appliquée-UGANC/LEREA, Conakry, Guinea \\ Email: mtambanicolas@yahoo.com
}

How to cite this paper: Millimono, T.N., Sall, S.M., Badiane, D., Bah, A., Diakhate, M., Toure, I., Barry, M.B., Diallo, D. and Diaby, I. (2017) Analysis of Bushfires Spatial and Temporal Variability in Guinea. Atmospheric and Climate Sciences, 7, 463-475. https://doi.org/10.4236/acs.2017.74034

Received: July 15, 2017

Accepted: September 24, 2017

Published: September 27, 2017

Copyright $\odot 2017$ by authors and Scientific Research Publishing Inc. This work is licensed under the Creative Commons Attribution International License (CC BY 4.0).

http://creativecommons.org/licenses/by/4.0/

\begin{abstract}
Guinea is confronted to the increasing risks of bushfires that destroy thousands of hectares of vegetation cover every year. Very little research is devoted to the variability of those fires, which makes it a serious threat to both wildlife and human habitats. The current study investigates the spatial and temporal distribution of bushfires in the period from 2003 to 2016. The method used is the geospatial technology: we first filter pixels corresponding with active light supplied by MODIS images (Moderate Resolution Imaging Spectroradiometer) and estimate their densities following the square meshing procedure. Burned areas are deducted from the estimated pixel densities by calculations. The results highlight great occurrence of fires: 4 to 48 pixels of active fire per year and per $100 \mathrm{~km}^{2}$ depending on the location; 2 to 5 million hectares per year of burned areas (20,000 to 50,000 sqkm). Almost 8 to $24 \%$ the size of the whole country. The prefectures of Beyla, Siguiri, Kouroussa, Kankan, Dinguiraye, Mali and Tougué are the most exposed areas. Every year, fire activities are observed as from October and between May and June. They are however mitigated according to the regions (or the geographical domains). Summits of bushfires activities are generally reached between December and January.
\end{abstract}

\section{Keywords}

Guinea, Bushfires, Variability, MODIS

\section{Introduction}

The Republic of Guinea is located in south-western part of West Africa, between 
$7^{\circ} 05^{\prime \prime}$ and $12^{\circ} 51^{\prime \prime N o r t h ~ l a t i t u d e ~ a n d ~} 7^{\circ} 30^{\prime \prime}$ and $15^{\circ} 10^{\prime} \mathrm{West}$ longitude, halfway between the Equator and the Tropic of Cancer. It covers an area of $245,857 \mathrm{~km}^{2}$. The country has diverse ecosystems and receives a rainfall up to $4000 \mathrm{~mm}$ per year, depending on areas. According to the national monographic survey on biodiversity of November 1997

(https://www.rmportal.net/framelib/monographie-de-la-guinee-sur-la-diversitebiologique.pdf), there are sites of great ecological interest that are protected on one hand (some of which are internationally recognized), and coastal zone, on the other.

A great deal of protected sites of world renown are located in Forest Guinea: Diécké and Ziama (tropical forests), the Nimba and Béro mountains and a dozen of small other forests. Other sites are the Kounounkhan Forest, a large mesophilic primary forest of Maritime Guinea, the Nyokolo-Badiar National Park at the center of the country, the Mafou National Park in Upper Guinea. On the coast, mangrove areas are listed as wetlands of international importance. This important inheritage is seriously degraded nowadays and threatened to disappear under influence of man that uses without any precaution fire as a working tool.

In Africa, scientific researches on bushfires focused on savannahs in the south of the continent, mainly with SAFARI 92 and SAFARI 2000 [1] [2]. While less and less diversified research on savannahs in West Africa is conducted [3] [4] [5].

Bushfires, apart from their destructive effects on ecosystems, are an important source of greenhouse gas emissions and aerosols in the atmosphere. These emissions strongly affect the climate, the global radiation balance, the air quality, human health and the economy. They are an important study center in several scientific domains: climatology, numerical weather prediction, risk prevention or forest management [6].

The study of general characteristics of bushfires is based on a wide variety of techniques operating at different scales, spatial and temporal. In the study of the general characteristics of bushfires and their impact on climate, satellites are one of the main sources of information. Despite their limitations in terms of resolution, they provide a global coverage and observe fires, vegetation and burned areas altogether.

In sub-humid Africa, space is mainly occupied by high herbaceous vegetation (up to 3 meters) and densely perennial grasses sort of Andropogon, Hyparrhenia, Loudetia, Panicum... [7]. At the end of the rainy season, these perennial grasses that have finished setting their seeds dry out and lignified. When the fire occurs, significant damage can be recorded on the biomass.

In some countries in West Africa such as Burkina Faso, Senegal, Côte d'Ivoire, etc., there has been a significant change in handling bushfire issues in the environmental policies [8]. As for Guinea, the challenge is still important due to limitation of resources. The Guinean environment is under a very precarious 
balance in comparison with the negative impacts of fires on natural resources. Some recent works by the Center for Ecological Monitoring (CSE/Senegal) has shown the consequences of those fires, but only for some prefectures in the Northeast, along the basin of the Senegal River. However, many other areas are affected by the phenomenon. The question of estimating burned areas was addressed by Barry in 2015, showing the need for further analysis. It is within this framework that we are addressing this more comprehensive analysis of bushfire variability over the period 2003 to 2016 using MODIS data. Following a presentation of the data and methodology in Section II, the results and discussion are presented in Section III and in Section IV the Conclusion.

\section{Data and Methods}

We used MODIS data, which are now included in the bushfire study baseline data [6]. MODIS products of active fires allow to address the issue of the rate of fires taking into account space. The followings are open access data sites available online

(https://earthdata.nasa.gov/earth-observation-data/near-real-time/firms/active-fi re-data). They are bi-daily with a spatial resolution of $1 \mathrm{~km}$. Bushfires are detected from a MODIS heat chain [9] [10]. Once extracted, active fire-points are classified in a reliability scale or a confidence interval of 1 to 100. For our research, only points of value between 75 and 100 were retained to establish a database containing the proven firing points. MODIS burned surfaces with a resolution of $500 \mathrm{~m}$ are available at $\mathrm{ftp}: / / \mathrm{ba1}$. geog.umd.edu/.

However, it should be noted that the spatial and temporal resolutions of the data have significant biases. Fires that occur before or after the passage of the satellite are not recorded. They may be under or overestimated by MODIS depending on the position and detection conditions, which creates a large disproportion between the number of detected fires and the estimated burnt area. From the values extracted from the zone of Guinea, we found a weak correlation, 0.47 between these two products. An illustration by comparing the normalized anomalies of these two data throughout Guinea and the period 2003-2016 shows strong phase offsets over several years (Figure 1).

On the other hand, by extracting the data with the same procedure in the case of administrative local zone in Guinea (prefecture zone), there is a certain coherence between the number of active fires and the burnt area (Figure 2). The correlation coefficient obtained is 0.76 . It led us to conclude that on this scale, the "burnt area" product can be a good proxy of active fires. Thus, the use of burnt surfaces allowed us to deepen the analysis of the variability of fires per year and per prefecture zone.

Unlike the detection of hot spots (for the detection of active fires), the MODIS "burned areas" product is not dependent on the time of passage of the satellite and is less sensitive to clouds or smokes. The combustion marks are more persistent than the fires that cause them. Burnt surfaces are used for tracking the period, location and extent of fires [11] [12]. 

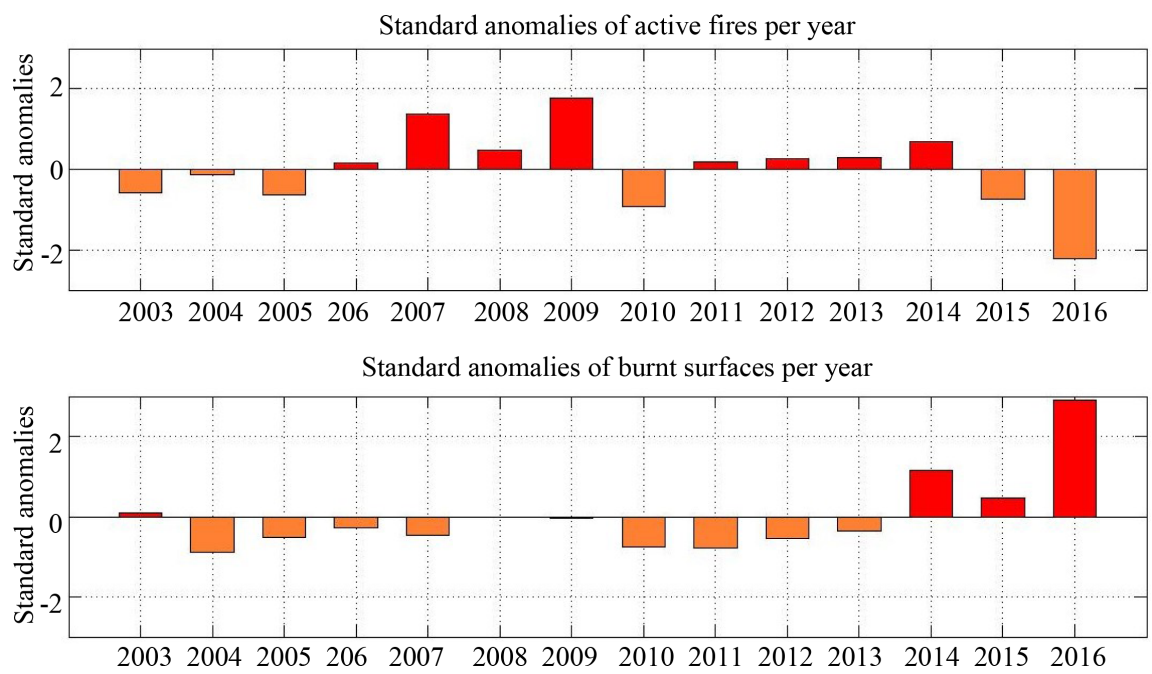

Figure 1. Standardized anomalies of active fires (top) and burned area (bottom) in Guinea over the period 2003-2016. As a whole the number of active fires is not equal to the burnt areas.
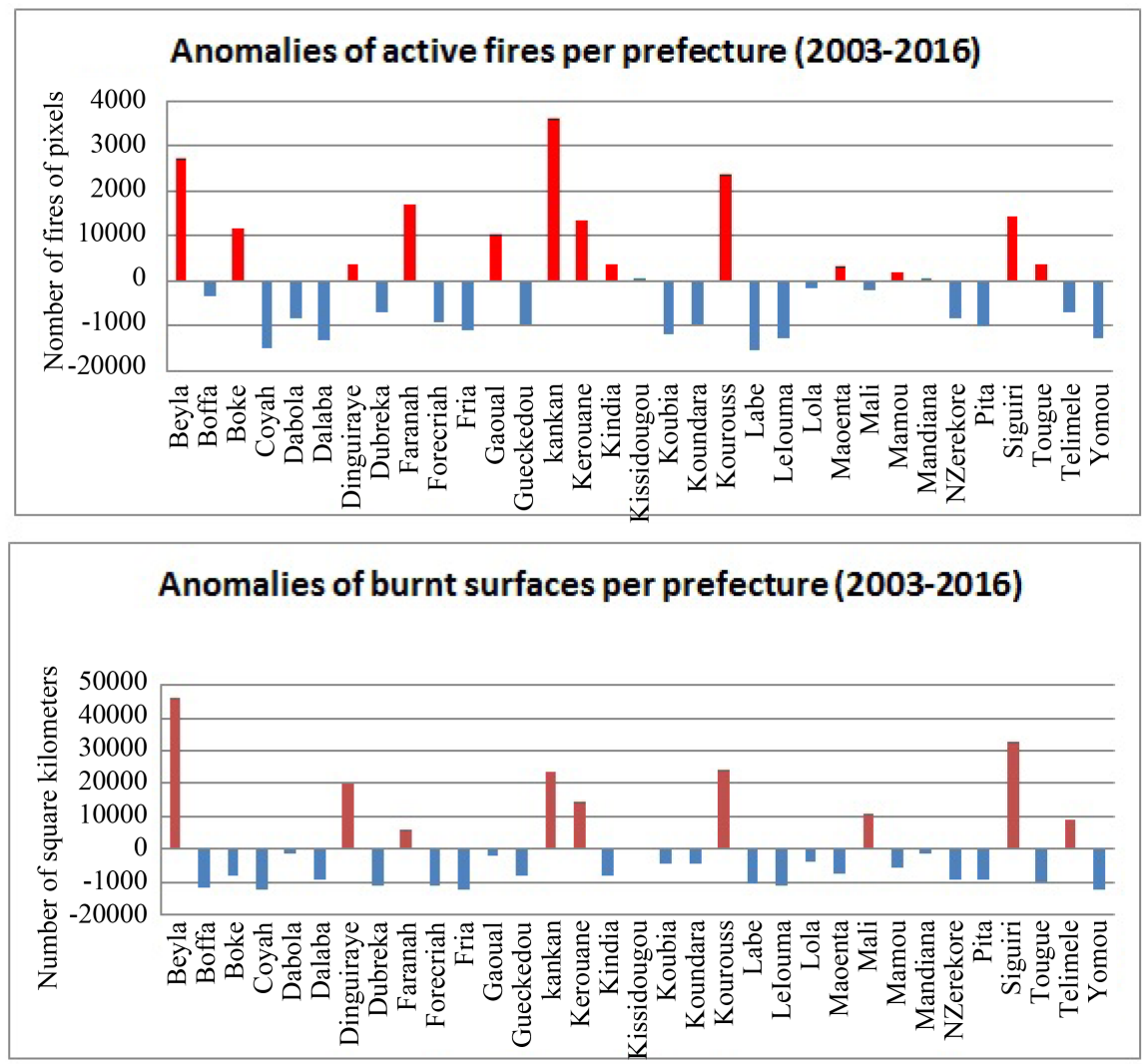

Figure 2. Anomalies of active fires (top) and burned surfaces (below) per prefecture zone (Guinea), over the period 2003-2016. Number of detected fires matches with the burned surfaces when analyzed at lower level.

Using geomantic methods, MODIS data on active fires and burned areas over the period 2003-2016 were organized using Geographical Information Systems (GIS), which were then estimated and aggregated to the Guinea area. The average 


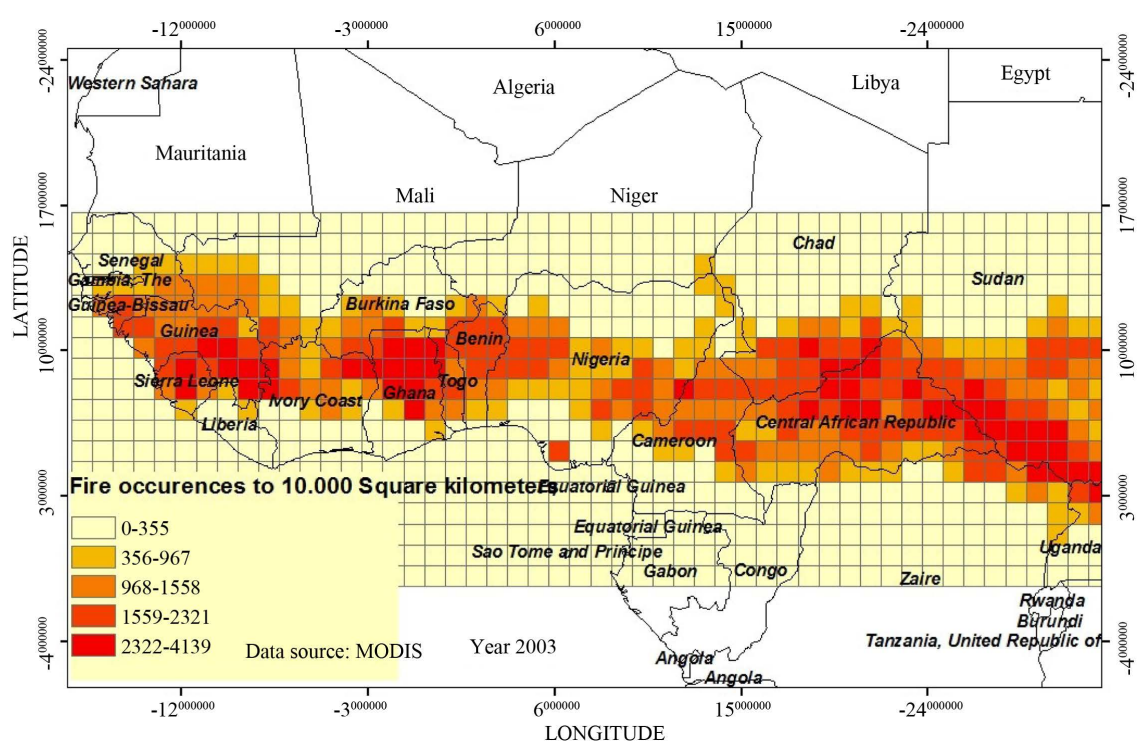

Figure 3. Density of MODIS fires in Sub Saharan Africa in 2003. Pixels of $500 \mathrm{~m}$ resolution accumulated in every square mesh of $10000 \mathrm{sqkm}$. High densities are recorded in Guinea.

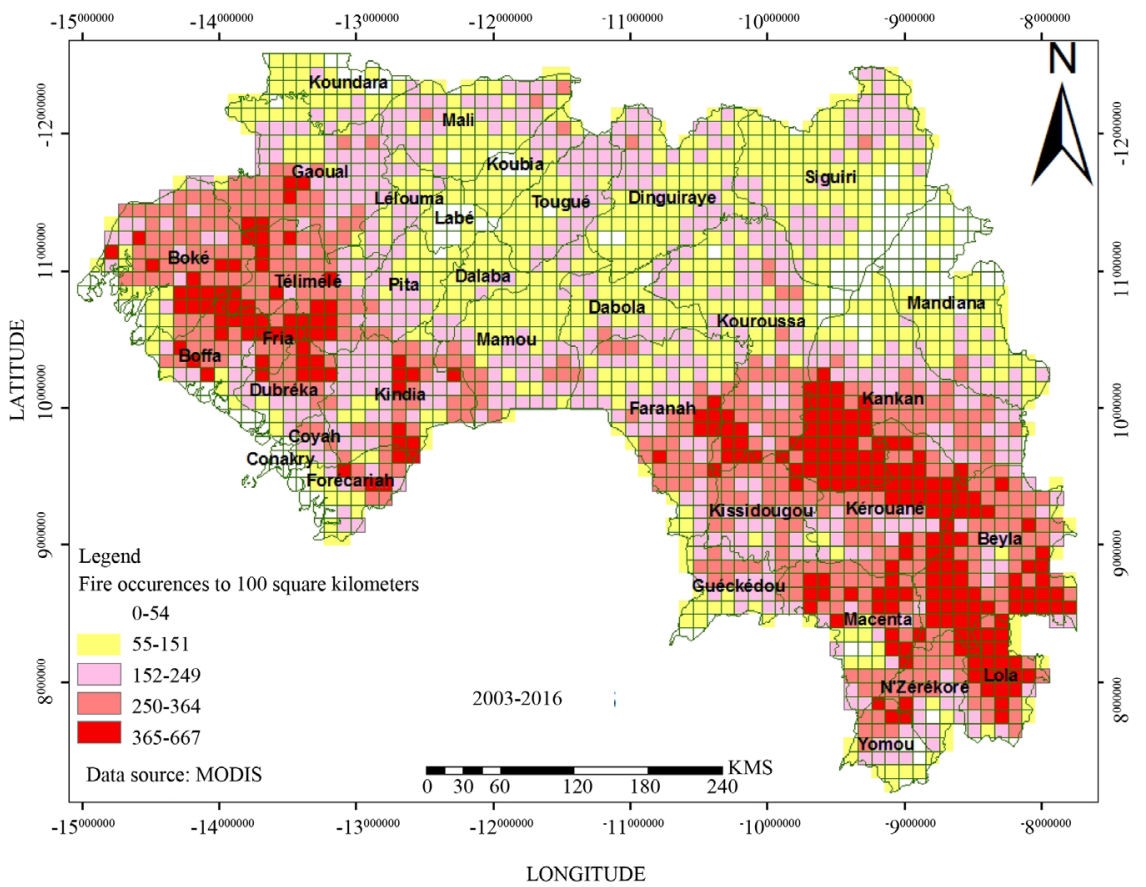

Figure 4. Fires main density in Guinea (2003-2016, pixels of $500 \mathrm{~m}$ resolution accumulated in every square mesh of $100 \mathrm{sqkm}$ ). Higher density of fires is observed in the western (lower Guinea) and Southern (Forest and Upper Guinea) regions.

density of lights was determined by the square meshing procedure with value transfer of all active light pixels, which enabled the calculation of fire density maps. The MODIS burned surface in shape file format allows to calculate the areas of fire traces. Their intersection with the map of Guinea makes it possible to determine on basis of prefecture zones, these surfaces. The monthly precipitations 


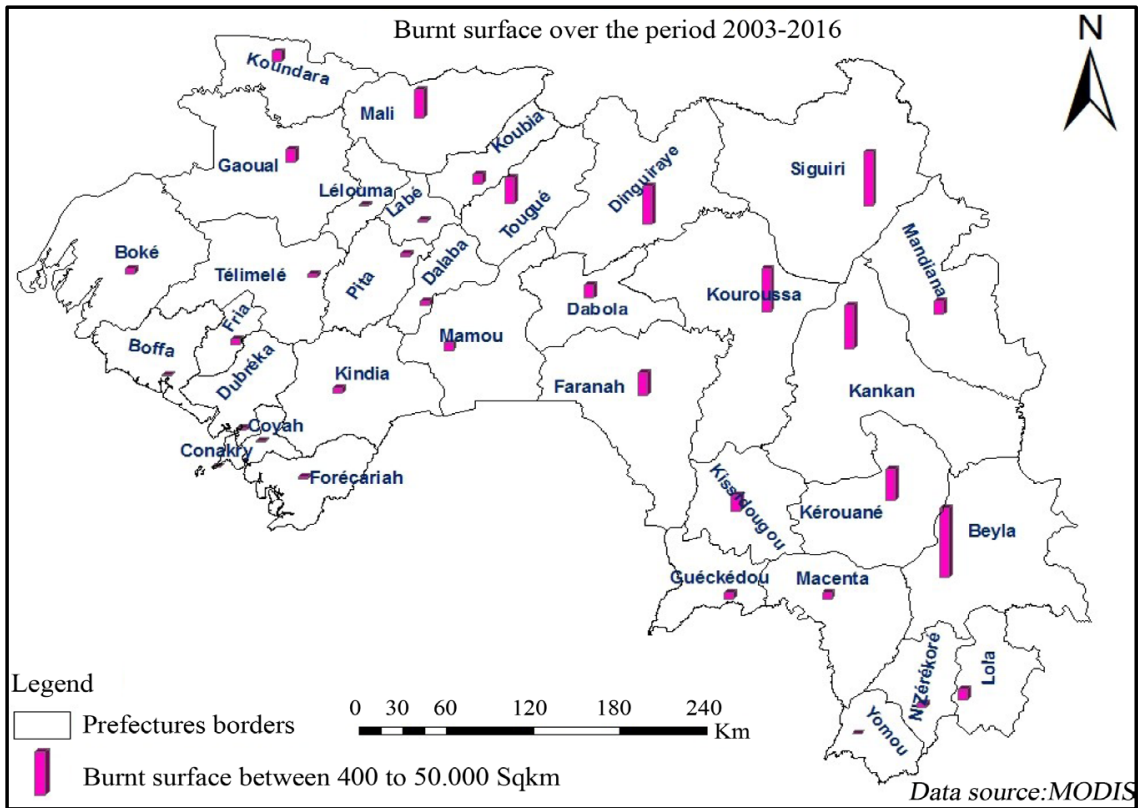

Figure 5. Spatial variability of burned surface in Guinea over the period 2003-2016. Quantities from 400 up to 50000 Sqkm were observed during the 14 years. An average of 28 to $3500 \mathrm{SqKm}$ of vegetation burned per year, with intensification in the savannah regions of the North-East.

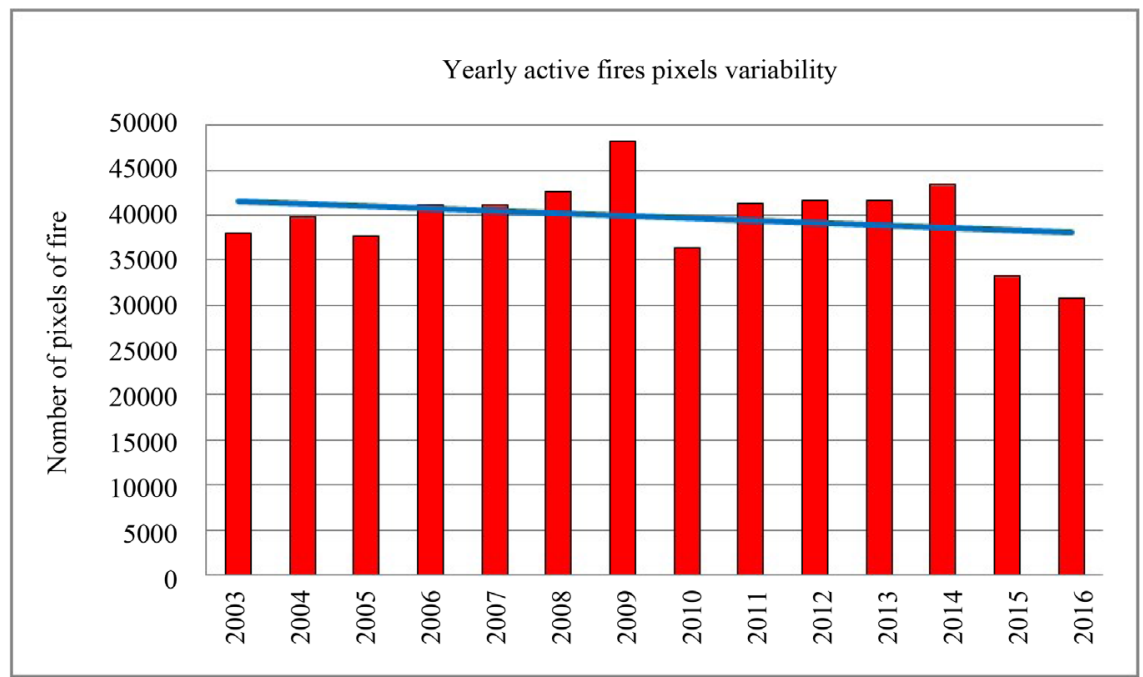

Figure 6. Inter-annual variability of active fire over the period of 2003-2016 (yearly total situation the whole country); The linear tendency in blue shows a slight diminution of fires. However 2009 and 2014 have been found critical in detected active fires.

data of the synoptic stations obtained during the period 2003-2013 helped to check the seasonal dynamics of the fires.

\section{Results}

\subsection{Spatial Distribution of Active Fires}

The area of West Africa records a significant number of bushfires per year. An 


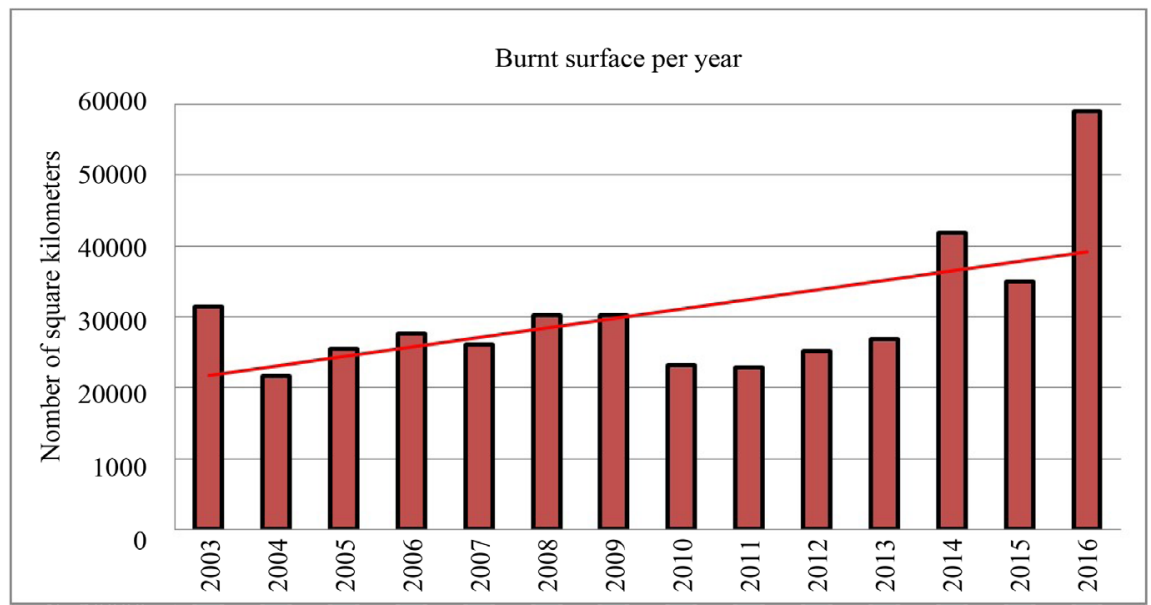

Figure 7. Inter-annual variability of burned areas during the period 2003-2016 (Yearly total situation of the whole country). The red-linear tendency shows an increase. The year 2016 has been found very critical.
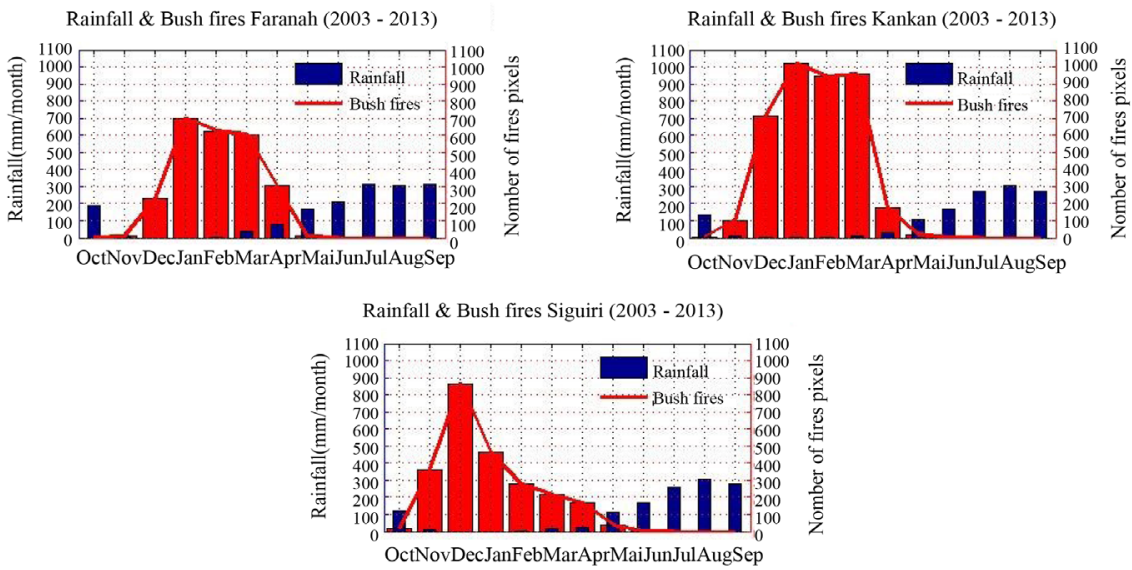

Figure 8. Seasonal variability of fires in the North of Guinea to Faranah, Kankan and Siguiri synoptic stations over the period 2003-2013. Fires are observed all along the dry season in those stations.
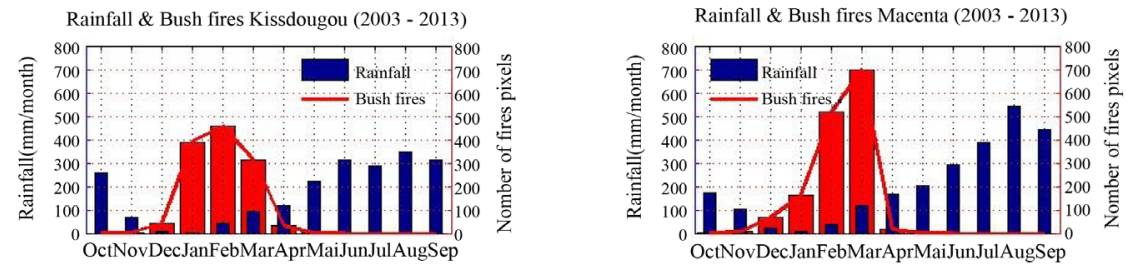

Rainfall \& Bush fires Nzerekore (2003 - 2013)

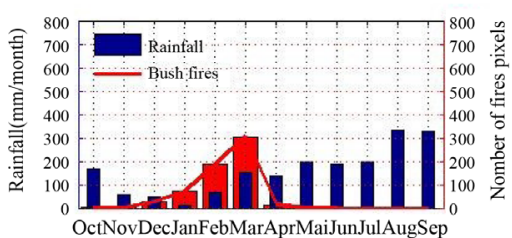

Figure 9. Seasonal variability of fires in the South of Guinea Kissidougou, Macenta and N'zerekore synoptic stations over the period 2003-2013. Fires are mainly observed during the months of January, February and March which is the farming period. 
average value of 2000 to 4000 pixels of fires at $10000 \mathrm{~km}^{2}$ (Figure 3). These fires are distributed unevenly among the different countries of the Sub-Saharan zone. Compared to other countries in West Africa, Guinea is one of the most affected.

Observations over the period 2003-2016 show a strong presence of bushfires on the Guinean territory with densities varying between 54 and 667 fire pixels per hundred (100) square kilometers during these 14 years, meaning 4 to 48 pixels per year per $100 \mathrm{Km}^{2}$ (Figure 4).

High densities are observed in the south and west of the country, with 300 to 600 pixels of fire recorded in each $100 \mathrm{~km}^{2}$ mesh during these 14 years of observation (Figure 4). This distribution shows the organization of fires and its disparities [13]. The lowest densities are recorded in the Northeast and on the Fouta Djallon massif. At the extreme north, biomass allows rapid but not regular spreading of fires, these fires can run over large spaces in a grassy vegetation. In the Fouta massif, shrubby plant formations and climatic conditions (humidity, temperature...) restrain bushfire activities, whereas in the South and West, the existence of a biomass of high density limitates the spreading of fires. While the biographical pattern partly explains the fires occurrence in these areas, the internal recomposition involving human activities and their agricultural practices is the basis of their variability. The populations of the South and West are predominantly peasant. They use fire for clearing their fields and the production of charcoal. While in the Northeast and Fouta Djallon (areas of agriculture and livestock farming), fire is a tool not only for clearing fields, but also for hunting or pasture preparation. These fires under certain conditions become uncontrollable and cause enormous damage to the ecosystems.

\subsection{Spatial Estimation of Burned Areas}

As already highlighted in the methodology section, the estimation of burned areas is a satisfactory approach to follow the traces of fires. Figure 5 shows that significant quantities of burned areas are recorded in the North and North-South. This is the case of the prefecture zone of Faranah, Tougué, Mali, Kérouane, Dinguiraye, Kankan, Kouroussa, Siguiri and Beyla, where quantities vary from 18858,88 to $58,994,25 \mathrm{Km}^{2}$ per prefecture zone over 14 years, to 421,000 hectares per prefecture zone and per year. These prefecture zones, with the exception of Beyla (on average $421000 \mathrm{ha} /$ year), belong to the savannah zones bordering the Sahelian zone.

On the other hand, in the South and West zones, the quantities of burnt areas by prefecture zone vary between 470.42 and $13541.04 \mathrm{~km}^{2}$ over the 14 years, an average of 3360 to 96722 hectares per prefecture zone and per year.

Small quantities of estimated burning areas in the southern and western zones would explain the sporadic nature of fires that are often used for specific activities (charcoal production, field clearing...). The vegetation in these areas is perennial, but does not allow fires to cover large zones. On the other hand, in the north and north-south, savanna zones favoring a rapid spread of fire, but the 
lack of big combustible elements throughout the year would explain the ephemeral nature of the fires in those areas, despite the fact that large areas are burnt.

\subsection{Inter-Annual Variability of Active Fires}

Figure 6 illustrates the annual variations in the number of active fires in Guinea between 2003 and 2016. There is a little inter-annual variability, with values between 30,000 and 47,000 fire pixels per year.

This figure shows that every year, large spaces are burned in Guinea, we note several years of an increasing phenomenon before a slight decline and for a short periods.

In comparison, [14] show a strong increase in the Sahel and West Africa countries, active fires detected between 2001 and 2005, followed by a slight decrease between 2005 and 2010. In Guinea, the period 2005-2009 is known for the increase of fires before observing a slight decrease in 2010. This clearly shows the impact of reducing the study of fires to the scale of ecosystems [15]. However, the linear trend shows a slight decrease in active fires over the period 2003-2016 (Figure 6).

\subsection{Inter-Annual Variability of Burned Areas}

Numerous burned areas have been recorded in Guinea over the period 20032016 in the range of 21725.94 to $59037.09 \mathrm{~km}^{2}$ per year, which means 9 to $24 \%$ of the country's surface area (Figure 7). The trend of burned areas is on the rise. The years 2014 and 2016 were the most prominent (41905.31 to $59037.09 \mathrm{~km}^{2}$ ).

If there are small variations between 2003 and 2013, the last three years (20142016) recorded significantly higher values. These results further confirm the critical state of Guinean ecosystems.

Analysis of the inter-annual variability of active fires and burnt surfaces proves that every year, large areas are burned in all the prefecture zones of Guinea. In the South and West, estimated burned areas would be limited because of significant clouds cover, but also because of the usage of fuels during farming. These ecosystems, where small burned areas have been recorded, are highly exposed due to the high occurrence of active fires.

\subsection{Seasonal Variability of Active Fires and Rainfall}

In Guinea, the rainfall regime is practically the opposite of the regime of fires. That regime follows a north-south gradient. Figure 8 shows the observation at three northern stations of the evolution of fires in relation with rainfall.

As we can see from these three stations, the period of fires varies between 4 and 6 months. The last rains are recorded practically in October, and the fires begins between November December, the summit is recorded in December on the station of Siguiri, located in the extreme north. The large number of fires observed in December at the Siguiri station is explained by the existence of a grassy savannah which constitutes a non-perennial fuel load. Faranah and Kankan, are 
two stations located between the north and the south of the country. The first summits of fires on these stations are observed in January, a slight stability of the fires from January to March is noticed; This stability of the fires is probably due to the position of these stations between dry savannah and wet savanna. The fuel load is virtually available throughout the year. These fires of the northern part are practically extinguished between April and May under the influence of the rains.

In the southern and western parts of the country, the rains persist until November, and there is a short dry season between December and mid-March. The first fires are observed more often between December and January with a peak is reached by February or March (Figure 9). Those peaks coincide with the farm burning period, which explains their amplitude during that period. Fires are extinguished in April on all three stations. In the south, fire phenomenon lasts only three months.

Globally, fires of the months of March and April are consequences of agricultural activities. The duration of the fires in the north is due to the long absence of rains and also to the multiple farming activities (breeding, agriculture, hunting ...).

\section{Discussion}

The spread of fires is not a hazardous event, it requires a certain number of conditions [16]. [17] made it possible to establish certain postulates: for example, the continuous grass (during certain period of the year) is one of the conditions for the spread of bushfires because it requires a minimum amount of biomass. On the other hand, combustible materials, such as herbs, leaves, etc. have to be dry enough to burn. Total fuel loads in Guinea grass stands vary remarkably, both spatially and temporally, over a relatively small island landscape.

In Guinea, these predisposing factors result in the existence of an adequate vegetation cover and a more or less long dry season following a north-south gradient. The northern part is a savannah zone where the rainy period is relatively short. Savannahs are very vulnerable to fires, which justifies the large burned spaces despite the low numbers of active fire pixels observed. In the south and west, the high densities of active fires are justified by the daily use of fire by farmers and charcoal makers. Those fires are generally selective and have a small number of burned surfaces. Given that southern rainfall is largely derived from forest evapotranspiration and the diminution of those forests would create long-term negative feedback that would disrupt the precipitation regime by increasing the length of the dry period. The frequency of droughts could be a determining factor in the frequency of fires in the forest region which is gradually being transformed into a savannah.

Analysis of the spatial and temporal variability of fires in Guinea involves two categories of settings: those related to human activities (farmers, hunters, breeders, charcoal makers ...) and those in relation with the environment (precipita- 
tion rate, fuel condition, temperature, etc.). Fires mostly anthropogenic can contribute to a utilitarian objective [4], the danger occurs when these fires take on an uncontrollable appearance especially when they occur at the end of the dry season, whereas the vegetation cover is virtually dried out. A better understanding of the spatial and temporal variability in fuel loads and moistures associated with invasive grasses is, therefore, integral to fire prevention and management in these ecosystems [18]. Considering their impact on the environment, fire issues become a challenge for the conservation of natural resources, the fight against climate change and the improvement of the living environment.

\section{Conclusions}

Our results show that Guinea is one of the West African countries where bushfires occur the most during the dry season. In fact, Guinean savannah differs from their Sahelian counterparts by a denser vegetation cover, the presence of shrubs, with a fairly large overall recovery rate. The rate of precipitation in those savannahs is higher than that of the Sahel, which favors a high production of grassy biomass. Large destructive fires occur almost every year, covering thousands of hectares throughout the dry period in Guinea.

The analysis of the spatial and temporal variability of fires for the period 2003-2016 made it possible to notice their recrudescence in space and in time. These fires cover millions of hectares per year and are observed in all prefecture zones. The total area burned per year varies between 2 and 5 million hectares ( $8 \%$ to $24 \%$ of the country's surface area) of which 100 to 600,000 ha per prefecture zone. The start of the fires is observed in October, they increase between December and January and their attenuation is observed between May and June according to the zones. Upper Guinea, Middle Guinea and Forest Guinea are the most affected regions. The Prefecture zones of Beyla, Siguiri, Kouroussa, Kankan, Dinguiraye, Mali and Tougué are mainly areas at risk. The increase in these fires is justified by the upward trend in the area burned during these 14 years of observation. It is therefore easy to understand the level of threat hanging over the Guinean ecosystems already weakened by other anthropogenic actions.

As any human activity, the current research is limited. While the MODIS spacial sensors are appreciable for active fires survey, the temporal ones still suffer some difficulties in zones such as Guinea. Fires that occur before or after the rolling of the satelite are unaccounted for.

There is also an insufficiency of data on the size of fires, therefore, small fires are most of the time ignored. The influence of clouds and the canopy considerably impacts on the detection of active fires in Guinea. The usage of the second MODIS product to estimate burned surfaces largely contributes in the analysis of the variability of fires. Burnt surfaces are the consequence of active fires; we therefore notice their increase in Guinea during the recent years.

The current study could be completed by field surveys to verify, not only the reflectivity of satellites to conditions on ground, but also to identify real causes 
of the variability of fires in Guinea.

We intend to continue this work by modeling the behavior of fire on the different ecosystems while explicitly observing other settings such as temperatures, soil moisture, wind types, florist composition, demography and socio-economic activities. Understanding these aspects would be useful in the search for methods to decrease bushfires events in Guinea.

\section{Acknowledgements}

Authors express their gratitudes to the following institutions and individuals: (i) To Guinean government through the Institut Supérieur des Sciences de l'Education de Guinée (ISSEG) for supporting research leading to this paper; (ii) To the Director of ISSEG for the choice of candidate and the support all along the activities; (iii) To the Laboratoire de Physique de l'Atmosphère et de l'Océan Siméon-Fongang (LPAO-SF) of the UniversitéCheikh Anta Diop of Dakar for the warm welcome and the creation of ideal working conditions; (iv) To all the supervisors and colleagues of the laboratory for the good spirit of collaboration that characterized the conduct of the research activities; (v) To the Laboratoire d'Enseignement et de Recherche en Energétique Appliquée (LEREA) of the University Gamal Abdel Nasser of Conakry for the establishment of a successful collaboration between the two institutes. Special thanks to the 3 anonymous reviewers for their constructive comments.

\section{References}

[1] Alleaume, S., Hely, C., Le Roux, J., Korontzi, S., Swap, R.J., Shugart, H.H., and Justice, C.O. (2005) Using MODIS to Evaluate Heterogeneity of Biomass Burning in Southern African Savannahs: A Case Study in Etosha. International Journal of Remote Sensing, 26, 4219-4237. https://doi.org/10.1080/01431160500113492

[2] Trollope, W.S.W., Trollope, L.A., Potgieter, A.L.F., and Zambatis, N. (1996) SAFARI-92 Characterization of Biomass and Fire Behavior in the Small Experimental Burns in the Kruger National Park. Journal of Geophysical Research: At mospheres, 101, 23531-23539. https://doi.org/10.1029/96JD00691

[3] Savadogo, P., Sawadogo, L. and Tiveau, D. ( 2007) Effects of Grazing Intensity and Prescribed Fire on Soil Physical and Hydrological Properties and Pasture Yield in the Savanna Woodlands of Burkina Faso. Agriculture, Ecosystems and Environment, 118, 80-92. https://doi.org/10.1016/j.agee.2006.05.002

[4] Sow, M. (2013) Caractérisation du risque de feu de broussedans les savanes du Sénégal par approcheexpérimentaleet par télédétection. [Specification of the Risks of Bushfires in the Senegalese Savannas of by the Experimental and Telemetric Detection Approaches.]

[5] Valéa, F. (2010) Etudes des feux de brousse au Burkina-Faso: Approches multi-échelles des feuxactifset des surfaces brûlées (Doctoral Dissertation, Caen). [A Study of Bushfires in Burkina Faso: Multiple Stage Approaches of Active Fires and Burnt Areas.]

[6] Thonat, T. (2013) Etude des feux de biomassetropicaux: Observation simultanée des gazémis par les feux à l'aide des observations hyperspectralesinfrarouges de AIRS et IASI. [A Study of Tropical Biomass Fires: Simultaneous Observation of Emitted 
Gazwith Hyperspectral X Rays of AIRS and IASI.] (Laboratoire de MétéorologieDynamique (LMD), CNRS, IPSL (EcolePolytechnique, Palaiseau/Paris).

[7] Bruzon, V. (1994) Les pratiques du feu enAfriquesubhumide, exemple des milieuxsavanicoles de la Centrafrique et de la Côte d'Ivoire. [Fire Practices in Sub Humid Africa, Case Study of Savannas of the Central African Republic and Ivory Cost.] In Blanc PamardCh., BoutraisJ., A la croisée des chemins, Paris, ORSTOM, 147-163.

[8] Valea, F., andBallouche, A. (2012) Les feux de brousseenAfrique de l'Ouest: Contraintesenvironnementalesououtil de gestionenvironnementale? [Bushfires in West Africa: Environmental Constraints of Environmental Management Tools?] L'exemple du Burkina Faso. Territoiresd'Afrique, 3, 36-47.

[9] Giglio, L., Descloitres, J., Justice, C.O. and Kaufman, Y. J. (2003) An Enhanced Contextual Fire Detection Algorithm for MODIS. Remote Sensing of Environment, 87, 273-282. https://doi.org/10.1016/S0034-4257(03)00184-6

[10] Mbow, C. (2004) Utilisation des donnéesbasse et moyennerésolution pour le suivi des feux de brousse et l'analyse des risquesd'incendie (MODIS, SPOT4-VEGETATION) [Usage of Low and Average Resolution Data for the Follow up and Analysis of Fire Risks.] In Journal des Sciences Pour l'Ingénieur, 5, 67-77.

[11] Roy, D.P., Boschetti, L., Justice, C.O. and Ju, J. (2008) The Collection 5 MODIS Burned Area Product-Global Evaluation by Comparison with the MODIS Active Fire Product. Remote Sensing of Environment, 112, 3690-3707.

[12] Boschetti, L., Roy, D. and Hoffmann, A.A. (2009) MODIS Collection 5 Burned Area Product-MCD45. User's Guide, Ver 2.

[13] Dolidon, H. and Le Drezen, Y. (2005) Les feux de brousseen Afriqueintertropicale: Un processusd'interface Nature Société. [Bushfires Tropical African Area: A Nature-Society Interface Process.] Exemplescomparatifs à partir de l'actuel et du passé, Séminaired'axe 1 de l'UMR 6554, enligne sur le site Internet de l'UMR 6554, 15-17.

[14] Garba, I., Touré, I., Ickowicz, A., Cesaro, J.D. and Toutain, B. (2012) Suivi des feux de brousse au Sahel. [Burshfires Survey in Sahel.] In : Touré, I., Ickowicz, A., Wane, A., Garba, I. and Gerber, P., Eds., Atlas des évolutions des systèmes pastoraux au Sahel: 1970-2012. FAO, Rome, 12-13.

[15] Sébastien, C. (2011) Le feu, la brousseet la savane. Modélisationspatiale de la dynamique des paysagessoudaniens (Burkina Faso). [The Bushfire, The Bush and The Savannah. Spatial Modelisation of Sudanese Landscape Dynamics.]

[16] Dolidon, H. (2007) La multiplicité des échellesdansl'analyse d'un phénomèned'interface nature/société. L'exemple des feux de brousseen Afrique de l'ouest. [The Diversity of Scales in the Analysis of an Interface Nature/Society Phenomenon. Case Study of Bushfires in West Africa.] European Journal of Geography, Cybergeo.

[17] Monnier, Y. (1981) La poussièreet la cendre, Paris, Agence de Coopération Culturelle et technique. [Dust and Ash, Paris, Technical and Cultural Cooperation Agency.] $253 \mathrm{p}$.

[18] Ellsworth, L.M., Litton, C.M., Taylor, A.D. and Kauffman, J.B. (2013) Spatial and Temporal Variability of Guinea Grass (Megathyrsusmaximus) Fuel Loads and Moisture on Oahu, Hawaii. International journal of Wildland Fire, 22, 1083-1092. https://doi.org/10.1071/WF12051 